\title{
足根管内で分岐する微細な神経分枝の解剖学的検討
}

\section{An Anatomical Study of the Calcaneal Nerve in the Tarsal Tunnel}

$\begin{array}{llll}\text { 安永 剛 } & \text { 工藤陽平 } & \text { 山下和彦 } \\ \text { 木 根一 典 } & \text { 橘 滋國 西島洋 司 }\end{array}$

Takashi Yasunaga, M.D., Yohei Kudo, M.D., Kazuhiko Yamashita, M.D., Ph. D., Kazunori Kinone M.D., Ph. D.,

Shigekuni Tachibana M.D., Ph. D., Yoji Nishijima, M.D.

\begin{abstract}
Tarsal tunnel syndrome is a not uncommon clinical condition. We have operated on 71 patients (125 feet) with tarsal tunnel syndrome over a two year period (2005-2006). During surgery we frequently found fine branches originating from the medial, lateral, or both plantar nerve within the tarsal tunnel. According to its origin and course we divided these into five patterns from 0 to 4 ; no fine branch, one fine branch from the medial plantar nerve, one fine branch from the lateral plantar nerve, two branches from the lateral and medial plantar nerve, two branches from the medial and lateral plantar nerve and forming an ansa, respectively. As a result our patients could be categorized as 51 (41\%) group 0, 49 (39\%) group 1, 3 (2\%) group 2, 15 (12\%) group 3, and 7 (6\%) group 4. Although these fine branches presented in more than half of our cases we found that very little attention has been paid to this ahatomical feature's existence. To recognize the existence of anatomical variations is important in avoiding accidental nerve injury during operation.
\end{abstract}

(Received : October 7, 2008 ; accepted : January 21, 2009)

\section{Key words}

tarsal tunnel syndrome, anatomy, medial and lateral plantar nerve, calcaneal nerve

\section{緒 言}

足根管症候群は踵を除く足底異常感覚を主訴とし, 内 側顆部で内側足底神経（medial plantar nerve；MPN）お よび外側足底神経（lateral plantar nerve：LPN）が絞扼さ れ発症する。症例は高齢者に多く, 腰椎疾患との合併例 がしばしば存在し腰椎術後に遺残する足底異常感覚の鑑 別診断上重要である.治療としての神経除圧術は有効で あるが，われわれは神経除圧術に際し足根管内で MPN あるいは LPN より分岐する微細な神経分枝 (calcaneal nerve）の存在を多数例で経験した．自験例の手術所見か らこの足根管内で分岐する微細な神経分枝の解剖学的検 討を行った。

\section{対象と方法}

$2005 \sim 2006$ 年の 2 年間に経験した自験 71 手術例 125 足（平均年齢 72 歳, 男性 38 例 64 病変, 女性 33 例 61 病変）の手術記録を再検討し，微細な神経分枝の存在と その分岐様式について分類した，術中に神経分枝が確認 できなかったものを group 0（Fig. 1 a)，MPN からのみ 分岐するものを group 1 (Fig. 1 b), LPN からのみ分岐 するものを group 2 (Fig. 1 c), MPN と LPN の両方から 分岐するものを group 3 (Fig. 1 d), さらに, この両者が 末梢で癒合し神経ワナを形成するものを group 4（Fig. 1 e）とした。局所麻酔下の術中に同神経に対し電気刺激 を行い，筋収縮の有無・患者の感じた刺激の放散方向を

西島病院脳・脊髄・ 心臟疾患センター / $\overline{4} 410-0022$ 沼津市大岡 2835-7〔連絡先：安永 剛】

Address reprint requests to : Takashi Yasunaga, M. D., Department of Neurosurgery, Nishijima Hospital, 2835-7 Oooka, Numazushi, Shizuoka 410-0022, Japan 

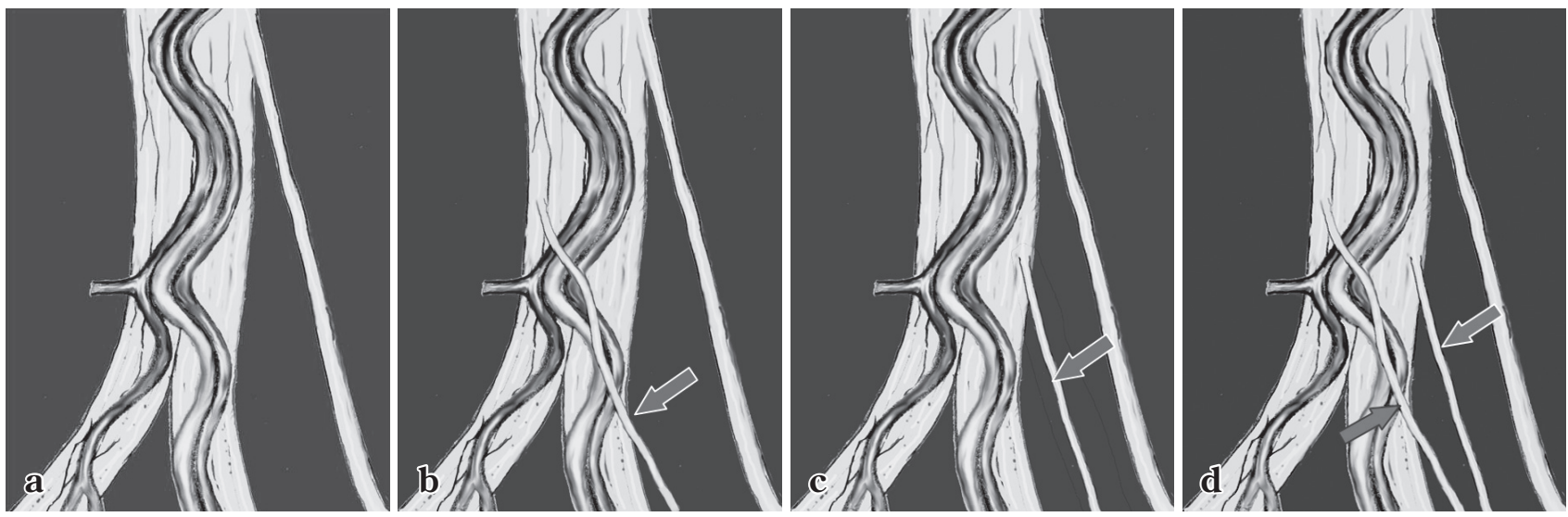

Fig. 1 Grouping of branching pattern

a : group 0 , no fine branch.

b : group 1, branch from the MPN.

c : group 2, branch from the LPN.

d : group 3, branches from the MPN and LPN.

e : group 4, branches from the MPN and LPN forming an ansa.

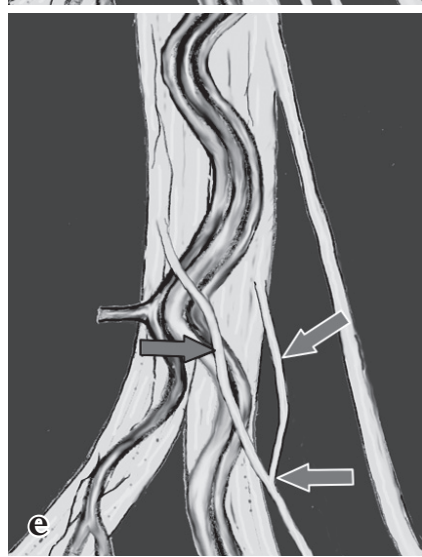

Table 1 The numbers of patient in each group

\begin{tabular}{ccr}
\hline & No of cases & $\%$ \\
\hline Group 0 & 51 & 41 \\
Group 1 & 49 & 39 \\
Group 2 & 3 & 2 \\
Group 3 & 15 & 12 \\
Group 4 & 7 & 6 \\
\hline
\end{tabular}

確認した。

\section{結 果}

Group 0 は 125 足中 51 足 (41\%), group 1 は 49 足 $(39 \%)$, group 2 は 3 足 $(2 \%)$, group 3 は 15 足 $(12 \%)$, group 4 は 7 足 $(6 \%)$ で過半数の症例に微細な神経分枝 の存在が術野で確認された（Table 1)。いずれの神経分 枝も medial calcaneal nerve, inferior calcaneal nerve より 明らかに細く, 同神経とは異なるものであった。特に MPL から分岐する分枝（group 1, group 3, group 4) は足根管 内で血管群の浅層を横切り, 屈筋支帯が単母趾外転筋の 筋膜に移行する部位でこれを貫通し皮下を走行していた ため，同部位の開放にはこの神経損傷を行わないように

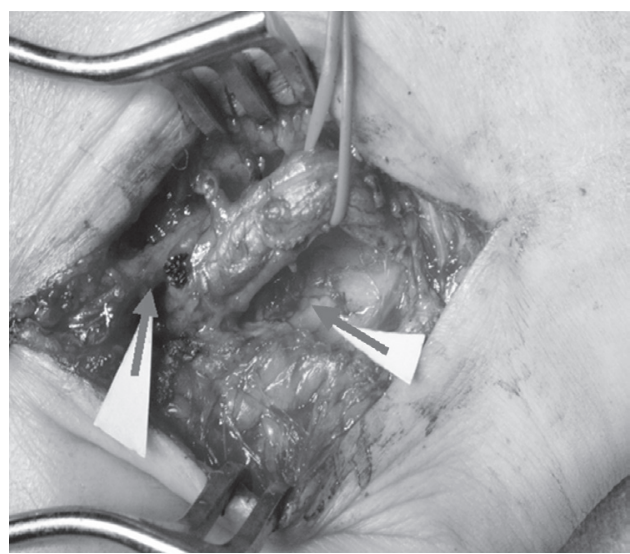

Fig. 2 Operative findings of the right foot

Right arrow : LPN, left arrow : a branch arising from the MPN and runs across the vessels.

\section{配慮した（Fig. 2).}

この神経分枝の術中電気刺激ではいずれの筋にも筋収 縮は誘発されず，患者は土踏まずに放散する電撃感を訴 え，皮膚神経であると考えられた。

125 足中 3 足に術後一過性の土踏まず部分の狭い範囲に 


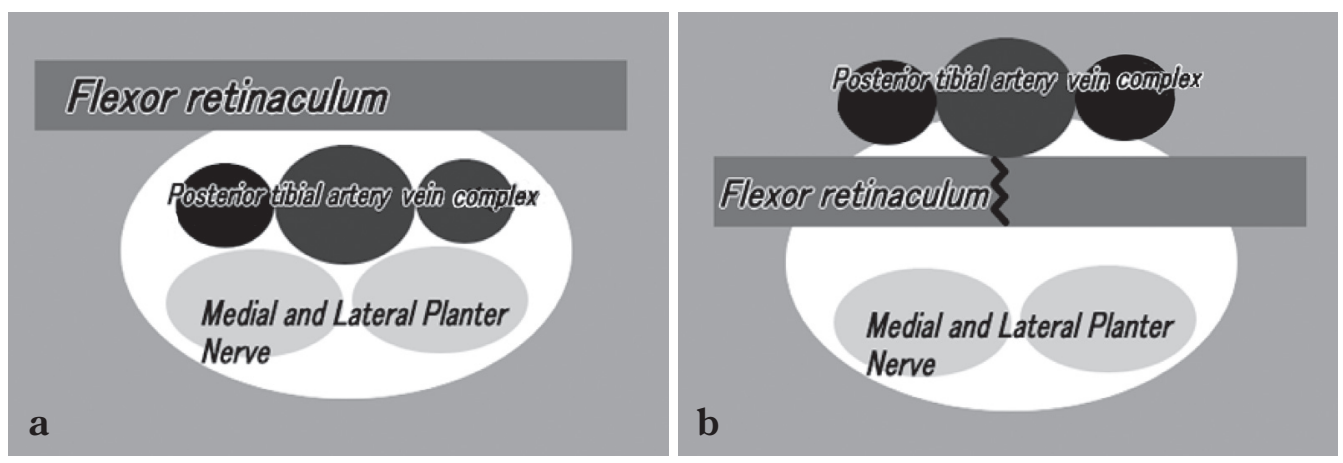

Fig. 3 Surgical method

a : preoperative schema of the tarsal tunnel.

b : reconstruction of the flexor retinaculum dividing between the nerves and the vessels.

限局する感覚低下を経験した。これは同神経の一過性障 害と考えられた。

\section{考 察}

絞扼性末梢神経のうち足根管症候群は足根管内で後脛 骨動脈・外側足底静脈・内側足底静脈など MPN $\cdot$ LPN と伴走する血管群が存在することが特徵的である。足根 管とは屋根部分である屈筋支带, 底層の後脛骨筋腱およ び長母趾屈筋，長趾屈筋腱で構成する解剖学的トンネル を指すが，この狭いトンネル内で血管群と MPN・LPN が接触している解剖学的特徵が病態に大きく関与してい ると考えられる。足根管内でのこれらの動静脈の硬化性 病変, 骨棘性変化, 外傷の既往などにより canal 内の容 積は減少し, 絞扼され症状を呈する。足底部のしびれ感 や疼痛, じゃり道を歩いたような, あるいは足底に皮が 1 枚張っているような, などと形容される。この絞扼性 末梢神経障害という考えは古くからあり, 従来から足根 管開放術により除圧を図るという外科治療が行われてき た.さらに Kohno ら ${ }^{11}$ は屈筋支带の切除のみでは不十分 であると考え, 血管群と両神経の間に脂肪組織を置くこ とにより良好な成績が得られたと報告している。また， これ以外に MPN ・ LPN が短母趾外転筋の下面を通過する 部位での絞扼も考えられている2).こうした報告は足根 管症候群に総称される後脛骨神経障害は単一の原因では ないことを示唆している。しかし, 術中に絞扼部位を明 確にすることは困難である。そこで，われわれは従来か ら血管圧迫の解除と短母趾外転筋の筋膜下での絞扼解放 を同時に行うことを目的に, 屈筋支帯を切断した後, 両 神経の通過する部位でそれぞれ短母趾外転筋の筋膜切開 を行い, さらに両神経と血管群を分離し, 両神経と血管 群の間で屈筋支帯を再縫合し, トンネル内は神経のみが
通過するように再構築する方法を行ってきた（Fig. 3). このように足根管内での広範な神経除圧を行う場合, わ れわれが報告するような微細な神経分枝の存在が無視で きず，これらの神経を同定，温存することが重要である.

特にこの術式で最も問題となるのは MPN から分岐する 微細な分枝である。今回の結果で group $1 \cdot$ group 3 . group 4 群では血管群より深部にある MPN からの微細な 分枝が存在し，この分枝は血管群の上面でこれと交差す るように屈筋支帯の直下を走行し, 屈筋支帯が短母趾外 転筋の筋膜に移行する部位でこれを貫通して皮下を走行 する，MPN からの分枝のみならず，LPN からの微細な 神経分枝も同様な神経走行を辿り踵部へ向かう様子が観 察されるが足根管切開部位より後方を走行するため術中 損傷のリスクは少ない. 分岐の高位については術野で MPN や LPN から分岐していることがほとんどで, 短母 趾外転筋下を通過する部位の筋膜切開に際し容易に損傷 される可能性の高いことを意味している。

MCN の分岐様式については渉猟しえた限り Dellon ら³) の報告が歴史的に古く, その報告では後脛骨神経 (posterior tibial nerve；PTN）からの MCN の分岐にはさまざ まなバリエーションがあるとしている。しかし彼らの報 告には今回報告するこうした微細な分枝については触れ ていない.

自験例では術野で MCN を全例確認できた訳ではない. しかし微細な神経分岐は前述のごとく MPN や LPN から 直接分岐しており, Luisia らの報告している MCN の分 岐とは異なるものと思われる ${ }^{4)}$. Havel ら ${ }^{5)}$ は微細な MCN 分枝について分類し $79 \%$ は微細な分枝を持たず，11\%に MPN より，3\%にLPNより，1\%に両神経よりの微細な 分枝を足根管内で認めたと報告している。 2006 年 Govsa らは剖検例 50 足での $\mathrm{MCN}$ の解剖所見を報告し, $38 \%$ は 単一の MCN のみであったが， $62 \%$ では多数の多彩な分 
岐様式が存在し， $32 \%$ にPN から，18\%に LPN から， $12 \%$ に両神経からの微細な分枝を認めたと述べている6). この報告は今回のわれわれの結果にきわめて類似してい る.われわれの結果では LPN のみからの微細な分枝 (group 2) はわずかに $2 \%$ のである点が異なる。これ は, われわれの結果は術野での観察にもとづいたもので あり, group 2 では微細な分枝は血管群の後面を走行し上 面を走行しないため, 術野では観察できなかった可能性 が高い.しかし，こうした報告は解剖所見であり，神経 の分岐様式のみに注目し, 神経と血管群との関係につい ては言及していない. われわれの術式では除圧を最優先 とし，すべての神経分枝を確認することはしていないが, 症例の増加により神経と血管群の分離方法も多様化し, それに伴い LPN からの細かい神経分枝を確認すること が多くなっている. 今後 group $2 \cdot \operatorname{group} 4$ の症例が増加 する可能性も高いと予想される。これら足根管内で分岐 するすべての微細な神経を同定, 温存することが足根管 症候群に対する外科治療において重要であると考えてい る.

この微細な神経の損傷の報告として Kim ら ${ }^{7)}$ は医原性 の踵部の疼痛患者 15 例の再手術所見を報告している.

これらの症例は足根管症候群に対する神経除圧術など何 らかの外科治療を受け術後に神経腫形成による疼痛を生 じていたという。その発生部位 PTN, MPN, LPN 抢よ び複数個所で認められたとしている．特筆すべきはこの 15 例中 9 例が以前に行われた足根管症候群の手術におい て短母趾外転筋筋膜切開の際に MPN より分岐した微細 な分枝を損傷し，有痛性の神経腫が形成されたことが原 因であったとしていることである7).われわれはこの神 経の存在を認識し注意深い手術を行っているにもかかわ らず一過性の土踏まず部位の感覚障害を経験している。

Inferior calcaneal nerve や medial calcaneal nerve は, 術野 にてその同定が容易なため術中損傷する可能性は低い。
しかしこれらとは分岐の異なる微細な神経もその走行方 向や電気刺激にて踵部への電撃感を呈するなど, 既知の calcaneal nerve 以外のこれらの神経群は無視できないもの と思われる. 実際この合併症は微細な神経分枝の一過性 障害による可能性が高く, Kim らの報告にも共通する. このことは，これらの微細な分枝は MPN からの分枝が 多く, またその走行から損傷されやすいというわれわれ の結果を裏付けするものと思われる。

\section{結 論}

足根管内には微細な神経分枝が高率に存在し, この神 経損傷は術後疼痛の原因になることを認識し, 合併症回 避のために慎重な手術が必要であることを強調したい。

\section{文 献}

1) Kohno M, Takahashi H, Segawa H, et al : Neurovascular decompression for idiopathic tarsal tunnel syndrome: technical note. J Neurol Neurosurg Psychiatry 69:8790,2000

2) Mackinon SE, Dellon AL: Surgeru of the Peripheral Nerve. New York, Thieme Medical Publishers Inc, 1988, pp305-317

3) Dellon AL, Mackinnon SE : Tibial nerve branching in the tarsal tunnel. Arch Neurol $41: 645,1984$

4) Luisia $\mathrm{S}$, Masquelet $\mathrm{AC}$ : The medial and inferior calcaneal nerves: an anatomic study. Surg Radiol Anat 21: 169-173, 1999

5) Havel PE, Ebraheim NA, Clark SE, et al : Tibial nerve branching in the tarsal tunnel. Foot Ankle 9:117-119, 1988

6) Govsa F, Bilge O, Ozer MA : Variations in the origin of the medial and inferior calcaneal nerves. Arch Orthop Trauma Surg 126:6-14, 2006

7) Kim J, Dellon AL : Neuromas of the calcaneal nerves. Foot Ankle Int 22:890-894, 2001 